\title{
Pancasila And Economy Prophetic: The Reconstruction Efforts of Indonesian Economic Law
}

\author{
Nurjannah Septyanun \\ Universitas Muhammadiyah Mataram \\ nurjajustice@gmail.com \\ Tin Yuliani \\ Universitas Muhammadiyah Mataram \\ yulianitin@gmail.com
}

DOI: $10.23917 / j t l . v 2 i 1.11104$

Submission
Track:
Received:
04 May 2020
Final Revision:
04 July 2020
Available online:
31 July 2020
Corresponding
Author:
Nurjannah Septyanun
nurjajustice@gmail.com
Tin Yuliani
yulianitin@gmail.com

\begin{abstract}
Purpose: The transcendental paradigm's importance can change the demoralization of the economic sphere and affect the changing economic goals of Pancasila.

Methodology: Normative legal research was used with paradigmatic approaches and qualitative descriptive analysis.

Finding: The symbolic phenomenon of religious rituals is not merely ritualism in the concept of civil religion. However, it can penetrate the particulate partitions of the operational dimensions. Similarly, the prophetic paradigm, with its prophetic ethics in terms of liberation, humanization, transcendence, gives space to the fundamental beliefs of society in economics. Civil religion minimizes the ongoing dominance, hegemonic, and exploitative of anti-humanity. The prophetic paradigm and civil religion can be a great energy for realizing the Pancasila idealism, the first of the transcendental meaning.

Importance: The transcendental dimension of the First Precept is a turning point. The importance of the community's awareness and legal travelers is for the reconstruction of Indonesian economic law to realize the social justice of Pancasila.
\end{abstract}

Originality/Novelty: The Prophetic and civil religion paradigms become one of the bids on economic demoralization.

Keyword: Civil Religion; Prophetic ethics; Pancasila; Indonesian economic law.

\section{INTRODUCTION}

To interpret the third paragraph of the opening of the 1945 Constitution, the explanation of the Indonesian religious thought states that Indonesian people are a society that is so strong 
with Divine values. This idea explains the relationship between man and the creator, determined by the explicit provisions, which Thomas Aquinas argued, "The world is above the Divine order... Deity, the law of Godliness is supreme". Next, in the fourth paragraph or last paragraph, it explains about Pancasila, which consists of five precepts. Substantially, a concept is sublime and pure. It is sublime because it reflects the nation's values, which have been inherited from generation to generation and abstractly. It is pure because of the substance that concerns some fundamental aspects, both religious, economic, resilience, social, and culture, which have a participatory pattern. ${ }^{1}$

Pancasila was born out of the noble values of the nation in an unassimilated culture and religious system. Economic products are also referred to as cultural products. Culture as a product departs from the existence of education, arts, and moral customs. The cultural process is concretized by the thought process, integrated into actualization so that it will be realized in space and time dimension. Therefore, the economy discussed in this paper is the economy and activities that depart from the Indonesian society culture, creating a system, both the economic system and the legal system. At this point, it is considered a Pancasila economy, which materialized from the religious people's values and ethics in Indonesia.

Religiosity is identical to the concept and meaning of Deity. Natural Law Philosophy Basis is God's will in every creature. In the prophetic context, the object of study is the "revelation" of Allah Ta'ala through his verses, both written in the Kitab and Sunnah. ${ }^{2}$ In Indonesia, both beliefs and cultures are assimilated into one entity. Culture and belief are in the form of religion, principally in terms of vertical and horizontal dimensions. The vertical dimension is that there is a creator's intervention, the one true God who is absolute, singular, and unchanged. The prevailing horizontal dimensions and links between human beings and others are relative, compound, and continuously changing or dynamic. The current question is, Does the culture form a paradigm? Alternatively, is it the paradigm that shapes a culture? Musa Asy'arie $^{3}$ states that the cultural civilization is from time to time, all change so that the paradigm determined by cultural change and vice versa.

\footnotetext{
${ }^{1}$ Otje Salman dan Anton F. Susanto, Teori Hukum Mengingat, Mengumpulkan dan Membuka Kembali, Ed. Aep Gunarsa, PT. Refika Aditama, Bandung, 2007, Hal 158.

${ }^{2}$ Absori, et al., Hukum Profetik Kritik terhadap Paradigma Hukum Non Sistematik, Genta Publishing, Yogyakarta, 2015. Hlm XI.

${ }^{3}$ Musa Asy'arie, Ontology Ilmu, Materi Kuliah Filsafat Ilmu, Program Pascasarjana Universitas Muhammadiyah Surakarta, 2016.
} 
These changes include a strong and dominant paradigm of spirituality and a unilateral claim that encourage specific interpretations of public and religious spaces. In the study of religious psychiatrists, religion is divided into two: first, the face of healthy religion and intense spiritualism, thus encouraging people to grow and develop on ideal character models, characterized by tolerant attitudes not to impose a pluralist public space filled by individual interpretations of religion; Second, a religious face filled with violent acts.

The demoralization of public space is a severe threat to the nation's diversity. Several sociologists such as Robert N. Bella and Talcott Parsons offer civil religion interpreted differently from religious institutions (institutional religions) in the construction design of a pluralist society. Civil religion becomes a package of public ethics, overcoming the symbolic phenomenon of religious rituals. It offers a universal norm that penetrates the particulate partition of the institutional religion (Islam, Christianity, Hinduism, and others). Civil religion continues to draw inspiration from the institutional religion but operates in an acceptable operational dimension beyond the boundaries of formalism and religious particularism. ${ }^{4}$ Departing from this, Jeffrie Geovanie, in dozens of articles surrounding Islamic modernism issues and the social dimension of the political movement on behalf of Islam, asserted that worship in Islam has no meaning whatsoever not functional for personal and social righteousness.

The functional nature of the transcendental dimension is an essential factor in holding transcendental values in state life. The prophetic paradigm in prophetic ethics with its main principle is humanization, liberation, and transcendence, which will be a knife to analyze state significance. The efforts on a legal reconstruction in Indonesia are mainly in the field of economic law. The economic system of Pancasila, in the beginning, has placed the prophetic aspect as the highest point with the primary meaning of the Almighty. The economic law, which departs from the state law in the form of derivative laws, regulations, and private law in the form (agreements, contracts, Akad) that awakened in public social contracts tends to demoralize.

The occurrence of demoralization is identical to the form and formation of a culture. Culture as a personality formation through a particular process, one of which is education.

\footnotetext{
${ }^{4}$ Eko priyono, 2008, dalam Jeffrie Geovanie, Civil Religion Dimensi Sisial Politik Islam, PT. Gramedia Pustaka Utama, Jakarta, 2013, Hlm xiii.
} 
Organized culture in the education process that will give birth to personality and form a mindset. Personality becomes an integrated manifestation of education and culture. The form of demoralization is closely related to mindset. According to Haris Rusli ${ }^{5}$, mindsets (the war of mindset), which is being waged by the current foreign powers is intended to: first, "Kill" or destroy Weltanschauung or the view of life, which is the foundation of the values of "inner cement" or the adhesive of a very diverse nation. Sukarno, Hatta, and the founders of other nations formulated the people's view of life under the name Pancasila. Secondly, the direction of the mindset launched today aims to bury the conception of citizenship adhered to by the Constitution of our country. Citizenship concept binds and governs its citizens based on history through the Constitution, laws, and regulations of its derivatives. Now the citizenship concept is gradually being replaced by the concept of nitizenship of Internet citizen concepts, tied and directed by public opinion formed by the interest group of foreign capital power. The concept of citizenship is now gradually eroded by the influence of nitizenship. In the case of online transportation (Gojek, Grab, and others), it shows that the concept of nitizenship lubricating the state based on public opinion has succeeded in defeating the state's conception of the Constitution and its derivative rules. Third, according to the will and direction of the free market, ideology and the mindset operation also leads to the destruction of the nation-state concept, which stands for history, philosophy, and territory formed through the Constitution. The nation-state's concept that formed nationalism will be altered and transformed into a corporate-state that stands for the cosmopolitan view that all human tribes are a single community as citizens of the world that are not restricted by tribal walls and state borders. The corporate-state concept is a country concept that stands on corporate interests that only know producers and consumers, no longer know national boundaries and do not know citizens.

In the global condition, without feeling and readiness, the Indonesian nation has wholly entered into the wilderness forest, the ASEAN Economic Community (AEC) free-market. People live in the field of free markets, like living amid a wilderness that unites all kinds of species, animals, and insects in one stretch without borders. According to Darwin's evolutionary theory, laws are "survival of the fittest," the most powerful, most cunning, and self-adjusting that can survive and prevail in natural selection. The desire to prey on the nature of predators

\footnotetext{
${ }^{5}$ Haris Rusli Petisi 28, "Operasi Mindset" Telah Berhasil "Membunuh" dan Mengendalikan Arah Fikiran dan Perasaan Bangsa Kita, Seri 8, Note 23 Maret 2016, di akses pada tanggal 14 September 2016.
} 
will appear only when they are hungry. They will stop when it filled, so the balance of nature is always maintained.

Meanwhile, the type of predator born and shaped by the free market nature is thus not dangerous, sometimes present with the face of Angels, seemingly bringing help and new hope to modern life, the poison tastes sweet like honey. This type of predator only knows the hunger, but never knew the fullness, very greedy, expert of hoarding, and holds billions to trillions of various foods that fall prey from various continents and countries. Although free-market predators are not much compared to billions of human populations, the consequences of greed have spawned war and crisis, the welfare crisis, the economic crisis, the social and political crises. $^{6}$

Episodes of colonialism new forms, borrowing terms of Sukarno: neocolonialismimperialism (Neokolim), deprivation, foundation, walls, or boundaries between one and another country, were torn down. Streamlining economic domination and market mastery, predators create a free market system, with no regulatory barriers and tariffs, without walls restricting every country. They are present in a particular form, can be the face of the state, or as the face of international financial institutions, and very often come with a corporate face (multinational corporate) operating without form in the expansion and scramble market infrastructure, manufacturing, financial and banking markets, competition for natural resources, and others.

\section{RESEARCH METHOD}

Normative legal research was used with paradigmatic approaches. Normative legal research is a study of the legal elements or "Gegevens of het recht". ${ }^{7}$ These legal elements include elements of ideal and the element of riel. Ideal elements include moral desires and human ratios. ${ }^{8}$ Besides, paradigmatic approaches were employed. Anis Chariri argued that the paradigm strongly determines the view (worldview) of researchers in studying the phenomena, the ways used in the research, and the ways used in interpreting the findings. The paradigm will determine the standard and quality of a result of the correct, precise, and useful process. Paradigm has roughly

\footnotetext{
${ }^{6}$ Haris Rusli Petisi 28, Ancaman "Predator Dasamuka” Di Era Pasar Bebas Asean, Seri 5, Note 03 Januari 2016, Diakses pada 7 september 2016.

${ }^{7}$ Purnadi purbacaraka \& Soerjono Soekanto, sendi-sendi ilmu hukum dan tata hukum, Penerbit Alumni, bandung 1982, Hlm 14

${ }^{8}$ Soerjono Soekanto \& sri mamudji, penertian hukum normatif, suatu tinjauan singkat, , PT. Rajagrafindo Persada, Jakarta, 1985, Hlm 14.
} 
the same meaning as the theoretical framework, the conceptual framework, the frame of thinking, theoretical orientation, perspective, or approach. Subsequently, it was analyzed using qualitative descriptive analysis.

\section{RESULTS \& DISCUSSION}

\section{Economics of Pancasila Prophetic Paradigm: a Reconstruction Efforts of Indonesian}

\section{Economic Law}

The paradigm of law and legal sciences in Indonesia, as identified by Kelik Wardiono 9 that due to the emergence of problems in the study and development of law and legal sciences in Indonesia, is the dominance of the rational paradigm supported by the philosophical sect of positivistic law. There is a separation between science and religion, which poses a positive and negative impact.

Prophetic paradigm relations and the realization of prophetic legal ethics are in recognition of the existence of institutional religion in Indonesia. There are several views about the existence of the institutional religion, one of which is dominant in providing an interpretation of openness among religion, science, and technology. It is not separated from the values of religion in general, including Islam, which has a philosophical possibility for meeting science and technology. The possibility of having a mature philosophical foothold thanks to the discourse of religious and scientific integration brought by the latest scientific developments.

On the other hand, many doubt religious and scientific integralism. This doubt is necessarily based on the source of legal studies in Indonesia derived from the rationalist Roman law so that the prophetic law discourse departing from religious beliefs is thought to make the truth, is considered ideal and applies to everyone, and cons with the spirit of religious pluralism in Indonesia. ${ }^{10}$ This doubt is essentially not wrong because pragmatism is still a position that has not been able to dialogue with other paradigms and see this prophetic law at the level of existence, which is considered the spread of the famous Sekat in Indonesia.

The concept of civil religion ${ }^{11}$ known so far is different in the Indonesian context. According to Jeffrie Geovanie, in his writings on issues of Islamic modernism and the social

\footnotetext{
${ }^{9}$ Kelik Wardiono, Paradigma Profetik Pembaruan Basis Epistimologi Ilmu Hukum, Genta Publishing, Yogyakarta, 2016, Hlm 32.

${ }^{10}$ Tomy Michael, Eksistensi Ilmu Hukum Profetik di Masa Mendatang, Fakultas Hukum Universitas 17 Agustus 1945 Surabaya, makalah seminar, disampaikan pada konferensi ke-5 AFHI di Universitas Muhammadiyah Surakarta 17-18 November 2015.

${ }^{11}$ From an academic perspective, it was an American sociologist Robert N. Bella who popularized civil religion discourse; Of course, in the American context. He departs from the French history setting. At that time, the French Enlightenment thinkers
} 
dimension of political movements in the name of Islam, civil religion is a package of public ethics that must be upheld in this plural country. Worship in Islam does not mean anything if it is not functional for personal and social righteousness. The debate about religion and state relations is final. What is required is the substance of religious values so that the face of Indonesia does not dry up from the universal spirit of religion that can be shared jointly. ${ }^{12}$

In line with the case, prophetic ethics is generally applicable, namely calling for good, preventing evil, and believing in God (transcendence). Thus, prophetic ethics has three main principles: ${ }^{13}$ 1) humanization ${ }^{14}$, 2) liberation ${ }^{15}$, and 3) transcendence ${ }^{16}$, which is to return all matters of life to God. This principle is, in fact, an attempt to optimize human spirituality as a servant, and transcendence is expected to be the value of human consciousness, which is communal or social. Humanization and liberation are both solely sought after the principle of this transcendence.

faced with a religion that was interpreted predominantly and hegemonic by the system of Kelrikalism, where the clergy were generally bound by the regime. Therefore, civil religion in France since the beginning is characterized by anti-clerklism, in protest against the church, which is rigid. As a historical discourse, civil religion was the first time to come from J.J. Rousseau, in his classic work, The Social Contract, Rousseau outlined the very simple dogma of civil religion: the existence of God, the life to come, the reward for virtue and punishment for the opposite, and the removal of the intolerant religious stance.

The existence of God, for example, becomes a central civil religion dogma in America. President John F. Kennedy, in his speech on 20 January 1961, referring to the four references to the existence of God being the forerunner of this civil religion. Firstly, the talk of the Laws of Nature and Nature's God, especially related to the natural rights given to faithful human beings for freedom. Secondly, the pretty popular Kennedy statement "by the creator, was granted certain undetachable rights". Here, Jefferson participated in laying the legitimacy of the higher law, which was based on the classic Nature Law and biblical religion. Thirdly, "the supreme judge of our sublime intentions", and the fourth, indicates "a firm belief in the unwise protection of God". In the last two references, God's history in the view of the Bible (a Biblical God of History) appears to act as the judge of the world

Further, in the minds of Franklin, Washington, Jefferson, and the other leaders in America, except for radical circles such as Tom Paine, civil religion never and will refer to himself as a substitute for Christianity, and religion in general. In fact, as today affirmed by Christologist Prof. Olaf Scumann, "Civil religion is not a religious source for someone where he obtained his understanding of his identity and his social obligations. The source for that remains is the religion that exists, and civil religion should not and could not be empowered to be a substitute for the religions ".

${ }^{12}$ Op.Cit

${ }^{13}$ Hasnan Bachtiar, Profetisme, Muhammadiyah dan Gelombang Besar Globalisasi: Suatu Tinjauan Transformasi Social, The Center Religious and Social Studies, Malang, Volume 15 Nomor 1, juni 2012, Hlm 26-27.

${ }^{14}$ Humanitarianism sometimes replaced by industrialism. The orientation of profit that carried out through production (mode of production) forms a consumptive human mindset, even forming the consumption society. Thus, the market interest is a priority that serves only capital owners. Contrary to this, those who are far from capital ownership marginalized from the industrial community (eliminated). Humanization is a paradigm, where consciousness to humanize humans, is sought to answer the various problems of industrial society

${ }^{15}$ This effort becomes very important, because in every social structure, especially in the context of industrial-capitalistic society. There are not only the owners of capital and workers but also in progress dominative, hegemonic, and exploitative. In other words, there are oppressive classes that are also oppressed. Liberation, as the principle of prophetic ethics, is useful to create a neutral condition of "colonialism". Liberation means liberation or is for humanity in the presence of a tiranic social system.

${ }^{16}$ Furthermore, that God is a source of strength; God is the source of immortality and Dzat the most objective. All efforts of humanization and liberation are not reactive human thoughts and attitudes. Efforts to defend against humanity, such as in the presence of oppressive dehumanization, are not that the class of oppressive is replaced by the oppressed class as a new oppressive, but rather to neutralize efforts and lead to objective conditions. 
One of the economic concepts of Pancasila is in the thoughts of the founding fathers of Indonesia, namely one of the national economic figures, Bung Hatta. In his book, entitled Bung Hatta and the Islamic economy, Anwar Abbas wrote that Indonesia is independent, and the mind of Indonesian social democracy is expected to be contained in the 1945Constitution of the Republic of Indonesia, which outlines three points: first, concerning the basic statement of political and ideals of Indonesia, where independence is seen as the right of each nation and the obligation for the government to engage in implementing world order based on independence, lasting peace, and social justice. Second, the statement about the success of Indonesian political demands is the gift of God. With God's grace, there is a recognition that the Indonesia nation will not be independent if God does not bless it. God bless Indonesia's independence because the Indonesian people have it in earnest with their sacrifice. Third, the statement of Pancasila as a state ideology philosophy, namely the Almighty God, which is inhumane, the unity of Indonesia, humane society, and justice. ${ }^{17}$ Also, Hatta's economic thinking can be seen as a part of Islamic economic thinking, where Hatta saw that the universe belongs to God's property. Therefore, the economy must be held by spiritual values and humanity with its application. ${ }^{18}$ Islam as one of the religions in Indonesia and recognized by the national law of sustainability. Islam, in its direction and development in Indonesia, correlates with the birth of the Unitary State of the Republic of Indonesia and Pancasila, as in the first precept "The almighty Godhead". Pancasila is a ground norm that must be the basis of the birth of Islamic attachment with the birth of the concept of Pancasila, especially the first precept. "Esa" or one gives the form of monotheism, which is the most beautiful of the Islamic Ummah and is realized in the basic form of the Pancasila state. ${ }^{19}$

The application of the Deity values and humanity to the system and economic law by the state through its government is a manifestation of the moral responsibility of the legal nomads. On how to further apply the values of the Godhead and humanity, at least, it is necessary to look at the history of economic law in Indonesia, from the pre-independence era, the old order, the new order, until the current reform. Indonesia's economic history demonstrates the policies made by the parties deemed expert and competent in the field of economics and law. In some

\footnotetext{
${ }^{17}$ Anwar Abbas, Bung Hatta dan Ekonomi Islam, Ed. Mukkaer Pakkana, Jakarta Kompas Media Nusantara, 2010, Hlm 240-241.

${ }^{18}$ Noffellisa, Sistem Ekonomi Bung Hatta Sejalan dengan Konsep Islam, Era Muslim Media Islam Rujukan, di posting pada Kamis 14 Agustus 2008, didownload pada, Kamis 28 Oktober 2016.

${ }^{19}$ Nurjannah S, et,all, Hukum dan Perbankan Syariah: Dinamika, Konstruksi Paradigma Pembaharuan Hukum Islam di Indonesia, Muhammadiyah University Press, Surakarta, 2020, hlm 25-26.
} 
government policies, the Pancasila economic pattern has a socialist character, and on the other hand, some policies have a very capitalist character. The socialist and capitalist patterns, driven by Pancasila in the Indonesian economic system and influenced the legal system, became a struggle for the paradigm that wanted to restore the spirit of divine values and humanity to the true economy of Pancasila. Considering the identity of the Pancasila economy, like it or not, it is emphasized through the following paradigm in its foundation domain.

Presenting God in the House of Indonesia means all to the paths of the religion/belief work together to practice the divine glory, namely to do the right, the good, and the sublime. The second precept is the path and team between human beings (based on the first noble spirit) to uphold humanity, righteousness, and justice in the House of Indonesia. ${ }^{20}$

The history of economic policy in Indonesia's pre-independence period experienced colonialism, divided into several periods. The Dutch colonized Indonesia implementing various economic and legal systems that have been in force until now. The Dutch adopted various economic policies since the era of Vereenigde Oost-Indische Compagnie (from now on, referred to as VOC). The understanding adopted by Dutch is an understanding of mercantilism. The VOC had Octrooi rights. When the Dutch East Indies were British, the British attempted to change the earth's tax patterns and had been nearly two centuries applied by the Dutch with land rent (land tax). The policy was strongly influenced by classical sect theories manifested in economic activities, where the management of private plantations was controlled by the capital owners (capitalists) and the community as a land worker. The principles were absolute superiority, principle, laissez-faire, and laissez-passer, where the economy was handed over to the private (capital owner) when clearly the Dutch East Indies held power in the colony.

In the old order government, which was the starting point of Indonesian independence, economic conditions were deplorable. It was characterized by high inflation, as a result of more than one currency that was uncontrollable. These conditions became the basis for the old order government to make efforts in addressing the economic problems faced, such as cutting the value of money (sanering), the Fortress program which attempted to foster indigenous selfemployed, Nationalization De Javasche Bank became Indonesian bank with function as central bank and circulation Bank, and the Ali-Baba's economic system in the form of fundraising

\footnotetext{
${ }^{20}$ Absori, et.all, Cita Hukum Pancasila, Ragam Paradigma Berkepribadian Indonesia, Nurjannah Septyanun, "Ekonomi Kerakyatan untuk mewujudkan Keadilan Sosial yang Pancasilais”, Pustaka Iltizam, Surakarta, 2016, Hlm 116.
} 
collaboration between Chinese business people and indigenous entrepreneurs. At that time, Indonesia was running a guided democracy system so that the logical consequences of Indonesia's economic structure was etatism, where all things were regulated by the government. The Sukarno's interpretation and understanding at that time were that Pancasila, which had its real reality, had the five components squeezed into three precepts (Trisila), and once again reduced to the exposition. The Ekasila was interpreted as the Gotong Royong (working together), where the other percepts were lost. Another word for Gotong Royong is the collectivism of one of the words communism that dominated the government at that time.

In the era of the New Order government, economic and political stability became its main priority. The orientation of the government program was controlling inflation, saving the state financially, and securing the basic needs of the people. In the process, it turned out that the liberal economic system was implemented, where the indigenous entrepreneurs were unable to compete with non-indigenous entrepreneurs, and the government's etatism system did not improve the situation, so the government chose a mixed-economic system within the framework of the economic system of Pancasila. In this era, Keynes's theories were used by the government in a limited economic intervention; for example, in setting the Regional Minimum wage, expanding employment opportunities, and others.

The Reformation Era made Indonesia a democratic country, and the Indonesia nation protected economic, political, social, cultural, religious, and other rights fairly and equitably. On the other hand, national and state economic problems were increasingly emerging, such as corruption, collusion, and nepotism, which were against the law (a criminal offense), especially for the holders of government authorities who had the power and authority in regulating and managing economic and governance fields administratively and implementation. These problems were solved through economic recovery and legal outlaws, such as requesting postponement of state debt payments to the World Bank, the privatization policy of BUMN, the establishment of a corruption eradication commission, a policy of reducing fuel subsidies and rising fuel prices, and a policy of direct cash assistance for poor people who tended to pose other social. In the era of Susilo Bambang Yudhoyono's leadership (the era of reform), the economic vision and mission were firmly stated in the plan of medium and long-term development (RPJM/RPJP). ${ }^{21}$

\footnotetext{
${ }^{21}$ When viewed from the philosophy, direction, and purpose of development in Indonesia that development is carried out by attention to the principles of togetherness, fairness, sustainability, environmental integrity, independence, maintaining a balance of progress and national unity. On the other hand, development demands; has not strengthened the political
} 
Reflecting on those thoughts, in the current context, it is very difficult if not followed by the social and legal paradigm that supports it. Basically, the social and legal paradigm is always guided by a specific belief that sees the economy and law as two swords ready to be planted based on the variety of readings and interpretations of Pancasila for the foundation of economic law in Indonesia.

The Pancasila Inter-religiosity context has not won any party between religions and beliefs in God YME. Mochtar Kusumaatmaja, Alfian confirmed that Pancasila is a political ideology or role and political function. Sri Edi Sasono linked the Pancasila with the life (democracy) of the economy, especially the cooperation. Selo Soemardjan assessed Pancasila as a guideline to determine which values are deprivation and falsification. Mubyarto considered Pancasila economic politics as the foundation and objectives with moral consideration rather than the rationality. Bintoro Tjokroamidjojo measured Pancasila in the bureaucracy and governance apparatus in terms of systems and behavioral approaches. Besides, Safroedin Bahar connected Pancasila to HANKAM, which known as Dwi-fungsi ABRI (ABRI's dual functions.). ${ }^{22}$

The mindsets, which as at the beginning of this writing are carried out by the economic globalization forces that are the target to be "killed" or "mastered", were thoughts and feelings, not the physical body. Foreign powers have successfully infiltrated, mastered, grasped, and controlled us without form by shifting the concept pattern of citizenship that broadens nitizenship. This mindset operation has also changed the perspective of the state administrators and the majority of the Indonesian people under the power of neocolonialism so that the direction and condition of the state no longer exists, determined by the people's representatives and outlined by the Constitution but determined by public opinion formed through the operation of the mindset by utilizing information technology systems in the economic field.

institutionalization, state organizing agencies, and civic institutions; The low-internalization of democratic values in national and state life; A threat to the unity and unity commitments; And the tendency of unilateralism in international relations. The paradigm chosen and used in the 2004-2009 government, to realize the vision of a mission consisting of 1) the realization of the lives of peoples and nations that are safe, unified, harmonious and peaceful; 2) The realization of society, nation and state that uphold the law, equality, and human rights; and 3) The realization of an economy capable of driving increased employment opportunities and viable livelihoods, and providing a solid foundation for sustainable development. The paradigm in realizing the Mission's vision is "a common mindset" in the development, addressing, and drafting strategies and policy measures for the five-year future. These paradigms can be described as "sustainable and sustainably growing, with a balance between political and economic democracy, the establishment of an institutional system and the realization of good and clean governance, the fulfillment of the fundamental rights of people, and the improvement of the welfare of the nation" in order to realize a just and prosperous society as the establishment of the opening of the CONSTITUTION 1945.

22 Oetojo Usman dan Alfian (peny), Pancasila sebagai Ideology dalam Berbagai Bidang Kehidupan Masyarakat, Berbangsa dan Bernegara, BP-7 Pusat, Jakarta 1992 Hlm 168. 
The history of the world showed two major events that occurred within a decade, the mindset operation for the disintegration of the strongly ideological Soviet Union and the unification of two different states of ideology, West Germany and East Germany separated by walls. When the two major events occurred, most of the people in the country thus welcomed and were supportive joyfully. ${ }^{23}$ Seeing the Indonesia history that departed from the history of the Archipelago Kingdom, it can be found the collapse of large kingdoms, such as Majapahit, hence not caused by the invasion of other countries' military forces, but through foreign powers that moved to infiltrate and spread new views, taking advantage of the situation of "perestroika" and "Glasnot" that was ongoing when Majapahit reached its peak of success and physical advancement. The viewpoint of several state apparatuses and its people were successfully conquered, altered, and defaced; his mortification was vandalized, culminated in the collapse of the Kingdom. The concept that is being offered is the presence of the prophetic paradigm in the Pancasila economic system as an effort to reconstruct economic law in Indonesia, which is assumed as the image below:

Figure 1:

Developing the prophetic paradigm of the Pancasila economy

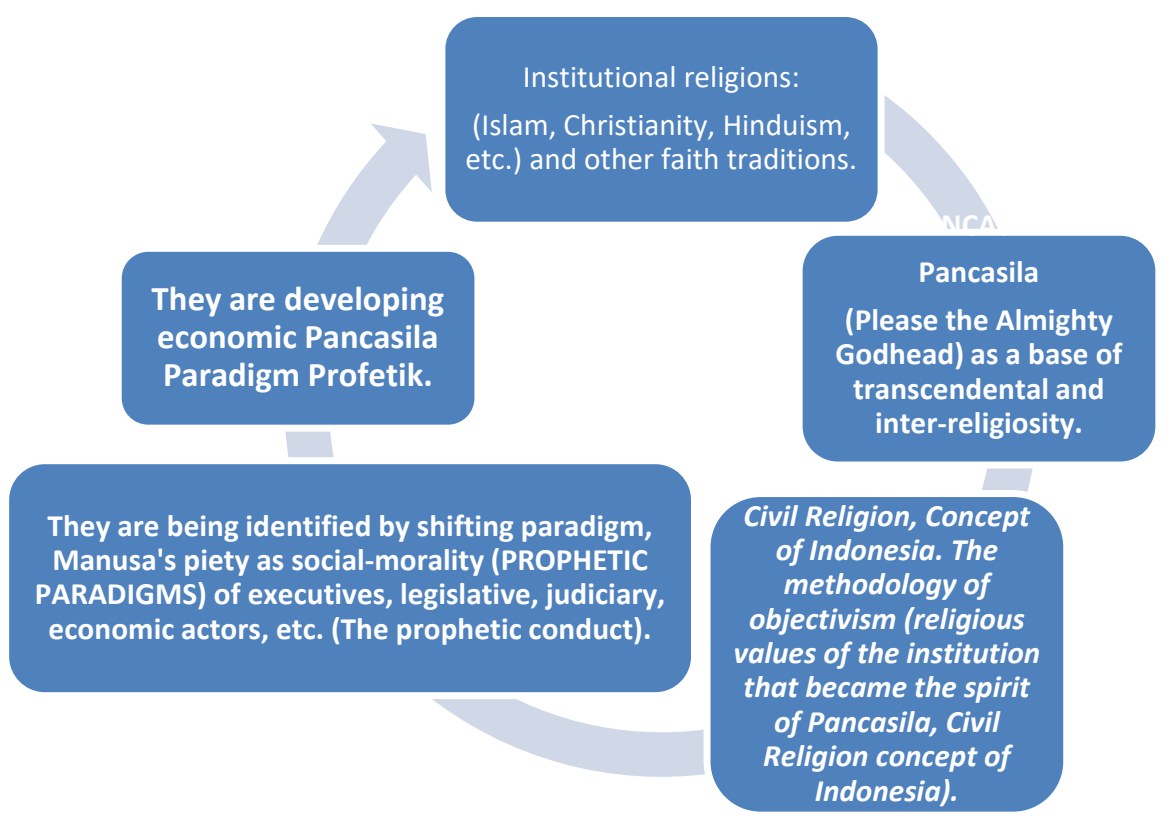

Promoting prophetic ethics contains three main principles of humanism, liberation, and transcendent. Besides, prophetic epistemology with Kuntowijoyo's objectivity methodology

\footnotetext{
${ }^{23}$ Op.cit
} 
becomes a very urgent pattern of the relationship to be examined to integrate the values of religion and science in social life, economics, politics, and others. The expectation is the realization of legal and economic systems that are conceptualized and instituted in the form of a prophetic economic law paradigm so that the nation's noble values are not affected by foreign influences that move massively in real and visible eyes through information technology. The Pancasila economy has a prophetic paradigm, an offer in reconstructing Indonesia's economic law that has been perceived as having been out of its main foundation, namely Pancasila, which is loaded with transcendental values. The products of law and legislation as an output of legal positivism have not provided regularity (order) within the community.

\section{CONCLUSION}

Humans are a fundamental functional part of the prophetic paradigm. The Kuntowijoyo objectivity methodology concept was created to build a prophetic paradigm, where the teachings of religious values are subjective and then objectified, giving birth to a shifting paradigm. The realization of individual righteousness extends to social righteousness as a form of outward morality - the concept of Civil Religion in Indonesia, which primarily departs from the functional dimension of religious values in public ethics. The Pancasila economy was born from the values of transcendence and inter-religiosity institutions in Indonesia, making the economic system and Indonesian economic law distinctive. Therefore, the Pancasila economy has a prophetic paradigm to be one of the reconstruction efforts of Indonesian economic law, which positions the Indonesian nation as Almighty in the foundational and functional aspects.

\section{REFERENCES}

Absori, et.all, (2015). Hukum Profetik Kritik terhadap Paradigma Hukum Non Sistematik, Yogyakarta: Genta Publishing,

Absori, et.all, (2016). Cita Hukum Pancasila, Ragam Paradigma Berkepribadian Indonesia, Nurjannah Septyanun, "Ekonomi Kerakyatan untuk mewujudkan Keadilan Sosial yang Pancasilais", Surakarta: Pustaka Iltizam.

Musa Asy'arie, (2016). Ontology Ilmu, Materi Kuliah Filsafat Ilmu, Program Pascasarjana Universitas Muhammadiyah Surakarta.

Eko Priyono, (2008). dalam Jeffrie Geovanie, Civil Religion Dimensi Sisial Politik Islam. Jakarta: PT. Gramedia Pustaka Utama. 2013.

Haris Rusli Petisi 28, (2016). "Operasi Mindset" Telah Berhasil "Membunuh" dan Mengendalikan Arah Fikiran dan Perasaan Bangsa Kita, Seri 8, Note 23 Maret 2016, di akses pada tanggal 14 September. 
Haris Rusli Petisi 28, (2016). Ancaman "Predator Dasamuka" Di Era Pasar Bebas Asean, Seri 5, Note 03 Januari 2016, Diakses pada 7 September.

Kelik Wardiono, (2016). Paradigma Profetik Pembaruan Basis Epistimologi Ilmu Hukum. Yogyakarta. Genta Publishing.

Tomy Michael, (2015). Eksistensi Ilmu Hukum Profetik di Masa Mendatang. Fakultas Hukum Universitas 17 Agustus 1945 Surabaya, Makalah seminar, disampaikan pada konferensi ke-5 AFHI di Universitas Muhammadiyah Surakarta 17-18 November.

Hasnan Bachtiar, (2012). Profetisme, Muhammadiyah dan Gelombang Besar Globalisasi: Suatu Tinjauan Transformasi Social. The Center Religious and Social Studies, Malang. Volume 15 Nomor 1 Juni.

Anwar Abbas, (2010). Bung Hatta dan Ekonomi Islam. Ed. Mukkaer Pakkana. Jakarta: Kompas Media Nusantara.

Noffellisa, (2016), Sistem Ekonomi Bung Hatta Sejalan dengan Konsep Islam, Era Muslim Media Islam Rujukan, di posting pada Kamis 14 Agustus 2008, didownload pada, Kamis 28 Oktober.

Nurjannah S, et,all, (2020). Hukum dan Perbankan Syariah: Dinamika, Konstruksi Paradigma Pembaharuan Hukum Islam di Indonesia, Surakarta: Muhammadiyah University Press.

Oetojo Usman dan Alfian (peny), (1992). Pancasila sebagai Ideology dalam Berbagai Bidang Kehidupan Masyarakat, Berbangsa dan Bernegara, Jakarta: BP-7 Pusat.

Otje Salman dan Anton F. Susanto, (2007). Teori Hukum Mengingat, Mengumpulkan dan Membuka Kembali, Ed. Aep Gunarsa, Bandung: PT. Refika Aditama. 